\title{
ANALISIS FRAMING BERITA PEMBERHENTIAN PSBB SURABAYA RAYA DI MEDIA ONLINE KOMPAS.COM DAN SUARASURABAYA.NET
}

\author{
Ruri Handariastuti ${ }^{1}$, Zainal Abidin Achmad ${ }^{2}$, Airlangga Bramayudha ${ }^{3}$ \\ ${ }^{1,3}$ Universitas Islam Negeri Sunan Ampel Surabaya \\ ${ }^{2}$ Universitas Pembangunan Nasional "Veteran" Jawa Timur \\ 1' rurihandarias@gmail.com, 2z.abidinachmad@upnjatim.ac.id, \\ ${ }^{3}$ bram.airlangga@gmail.com
}

\section{Article Info}

\section{Article history:}

Received 5 Agustus 2020

Accepted 8 September 2020

Published 1 Oktober 2020

\section{Keyword:}

COVID-19, Framing

Analysis, Pan and Kosicki,

PSBB

\section{Abstract}

This research discusses the Analysis of the News Framing of PSBB Surabaya Raya Termination in Online Media Kompas.com and Suarasurabaya.net Edition 8-9 June 2020. This research uses constructive paradigm using Framing Pan and Kosicki analysis method with the assumption that each news article has a frame which functions as a center of the organizational idea. Kompas.com dan suarasurabaya.net have their own views to frame their news. Kompas.com is a national online media, while for suarasurabaya.net is a local online media that much people interest in Surabaya, especially for radio media. The result shows news article has used some of them have a lack point and suarasurabaya.net more construct East Java Governor figure.

Artikel ini membahas tentang Analisis Framing Berita Pemberhentian PSBB Surabaya Raya di Media Online Kompas.com dan Suarasurabaya.net Edisi 8-9 Juni 2020. Penelitian ini menggunakan paradigma konstruktif dan representasi media dengan menggunakan metode analisis Framing Pan dan Kosicki dengan asumsi bahwa setiap berita memiliki frame yang berfungsi sebagai pusat gagasan organisasi. Kompas.com dan suarasurabaya.net punya pandangan dalam mengemas berita tersebut. Kompas.com ialah media online Nasional, sedangkan suarasurabaya.net merupakan media online lokal yang sangat banyak diminati di Surabaya terutama untuk media Radionnya. Dari hasil penelitian ini diketahuhi sebagian berita yang digunakan memiliki kekurangan dan suarasurabaya.net lebih menkonstruksi sosok Gubernur Jawa Timur.

Copyright (C) 2020 Jurnal Ilmu Komunikasi

\section{Editorial Office:}

Program Studi Ilmu Komunikasi, Fakultas Dakwah dan Komunikasi, UIN Sunan Ampel Surabaya. Jl. Ahmad Yani 117 Surabaya, Jawa Timur, Indonesia.

Email: jurnalilkom@uinsby.ac.id 


\section{Pendahuluan}

World Health Organization (WHO) menyatakan bahwa virus corona telah dikategorikan sebagai pandemi global. Pernyataan itu disampaikan oleh Direktur Jendral Tedros Adhanom Ghebreyesus dalam konferensi pers pada tanggal 11 Maret 2020. ${ }^{1}$ Dengan menyoroti kasus diluar negara China yang meningkat hingga 13 kali lipat, dengan jumlah negara yang terinfeksi meningkat tiga kali lipat. ${ }^{2}$

Sebagai antisipasi meluasnya penyebaran virus Covid-19, Indonesia menerapkan kebijakan untuk pencegahan yang berlaku sejak 2 Februari 2020. ${ }^{3}$ Setelah rapat terbatas kementerian luar negeri bersama Presiden Republik Indonesia (RI), Bapak Joko Widodo yang berlangsung di Bandara Halim Perdanakusuma. Pembahasan mengenai pemulangan Warga Negara Indonesia (WNI) dari Wuhan, penempatan lokasi observasi di pulau Natuna, larangan penerbangan langsung dari daratan utama China, larangan perjalanan bagi WNI ke daratan utama China, dan penghentian sementara pemberian fasilitas bebas visa kunjungan dan visa on arrivals untuk warga negara Republik Rakyat Tiongkok (RRT) yang bertempat tinggal didaratan utama China.

${ }^{1}$ WHO, "WHO Director-General's opening remarks at the media briefing on COVID-19, Juli 1,2020

https://www.who.int/dg/speeches/detail/whodirector-general-s-opening-remarks-at-the-mediabriefing-on-covid-19---11-march-2020.

${ }^{2}$ Ardi Priyanto Utomo, "WHO Umumkan Virus Corona sebagai Pandemi Global”, Juni 15, 2020,

(https://www.kompas.com/global/read/2020/03/
Setelah itu secara beruntun pemerintahan mengeluarkan berbagai kebijakan terkait pencegahan dan penanganan Covid-19. Pemerintah melalui Gugus Tugas Percepatan Penanganan Corona Virus Disease 2019 (COVID-19), setiap sore pada tayangan televisi secara nasional, menghimbau agar warga Indonesia tidak lupa menjaga kesehatan dan menjaga kebersihan di lingkungan rumah mereka terutama untuk diri mereka sendiri. Ini juga termasuk pencegahan di lingkunngan Istana Negara, dengan melakukan pengukuran suhu tubuh untuk tamu yang akan datang di istana. Dari hari kehari penambahan kasus virus corona terus bertambah baik ODP dan PDP hingga suspect.

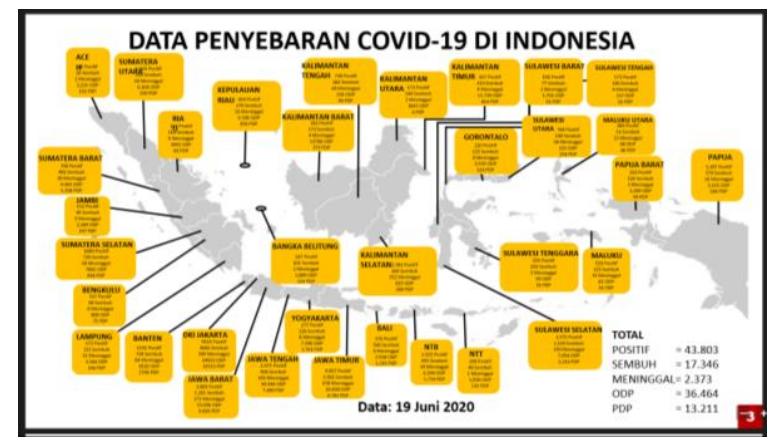

Gambar 1 : Data Penyebaran Covid-19 di Indonesia Periode 19 Juni 2020 (Sumber: Indonesia Indicator)

Tercatat hingga tanggal 19 Juni 2020, jumlah kasus virus corona terbanyak berada di DKI Jakarta tetapi secara statistik

12/001124570/who-umumkan-virus-coronasebagai-pandemi-global?page=all.

${ }^{3}$ Kemlu RI, "Pernyataan Pers Kemlu tentang Update Pemulangan WNI dari Wuhan serta kebijakan Pemri mengenai Pendatang/Traveler dari RRT”, Juli 1, 2020.

https://kemlu.go.id/portal/id/read/1128/siaran_p ers/pernyataan-pers-kemlu-tentang-updatepemulangan-wni-dari-wuhan-serta-kebijakanpemri-mengenai-pendatangtraveler-dari-rrt. 
menunjukkan angka penurunan secara signifikan. Sedangkan Jawa Timur berada pada urutan kedua menjadi kasus Covid-19 terbanyak di Indonesia, belum menunjukan statistic mengalami penurunan.

Dalam hal ini pemerintah bertindak cepat dalam menangani kasus ini, semenjak awal Maret mulai diumumkan bahwa terdapat warga Indonesia yang katakan ODP. Pemerintah terus menghimbau untuk menjaga kesehatan dan melakukan hidup sehat, menghindari orang yang sedang sakit batuk, hingga mulai menggunakan masker saat pergi keluar rumah atau saat bertemu dengan orang. Tidak hanya itu dari segi kesehatan pemerintah juga menyedikan rumah sakit , alat kesehatan yang memadai untuk persiapan jika nantinya terdapat penambahan kasus. Peraturan pun juga terus dibuat dan diperbarui terutama mengenai jalannya keluar masuk di negara Indonesia, dalam hal ini melalui konferensi pers pada akun youtube Sekertariat Presiden, pihak imigrasi mulai melarang masuk warga negara asing hingga melakukan kegiatan transit terutama dari daerah yang dilarang seperti China,Itali, Iran, dan Korea. ${ }^{4}$

${ }^{4}$ Sekretariat Presiden. "Live: Keterangan Pers Juru Bicara Coovid Pkl. 13.00, 12 Maret 2020", Juli 1, 2020.

https://www.youtube.com/watch?v=EVoQIdXAx4 g.

${ }^{5}$ Chyntia Lova, "PSBB Jakarta Mulai 10 April: Belajar Tetap di Rumah, Fasilitas Umum Ditutuip", Juli 1, 2020.

https://megapolitan.kompas.com/read/2020/04/ 07/21552791/psbb-jakarta-mulai-10-april-belajartetap-di-rumah-fasilitas-umum-ditutup.

${ }^{6}$ Pebriansyah Ariefana, "Data 65 Warga Jawa Timur Suspect Virus Corona, Ini Penjelasan
Tidak hanya pada imigrasi dan kesehatan saja, pemerintah membuat beberapa kebijakan. Setelah keluarnya kebijakan PSBB pertamakali di lakukan di Jakarta yang berlangsung pada tanggal 10 April, berlangsungnya PSBB juga dilakukan kegiatan belajar mengajar dirumah. $^{5}$ Bagi pekerja kantoran juga diberlakukan bekerja dari rumah yang disebut dengan WFH (Work From Home).

Tidak hanya di Jakarta, beberapa daerah juga mulai menerapkan PSBB untuk menanggulangi penyebaran virus Corona ini. Terutama di Jawa Timur sebagai kasus terbanyak nomor 2, dari tanggal 5 Maret diketahui di Jawa Timur ada 65 orang dinyatakan suspected virus corona, 34 di antaranya berasal dari Surabaya. $^{6}$ Ketika diketahui semakin bertambah kasus di Jawa Timur, Gubernur Jawa Timur mulai merencanakan untuk melakukan PSBB di daerah/ kota Jawa Timur terutama di daerah yang memiliki jumlah terbanyak kasus. Pada tanggal 19 April, tiga wilayah menyetujui pemberlakuan PSBB untuk mengurangi jumlah kasus di Surabaya yang terus melonjak yang sejak tanggal itu tercatat 1806 dinyatakan ODP di 31 kecamatan di Surabaya. ${ }^{7}$ Rencana itu akhirnya mulai

Dinkes" Juni 15, 2020, (https://jatim.suara.com/read/2020/03/05/14054 6/data-65-warga-jawa-timur-suspect-viruscorona-ini-penjelasan-dinkes.

${ }^{7}$ Achmad Faizal, "Risma dan 2 Kepal Daerah Lainnya Sepakat Akhiri PSBB Surabaya Raya, Khofifah Fasilitator, ’ Juni 22, 2020, (https://regional.kompas.com/read/2020/06/08/ 21172681/risma-dan-2-kepala-daerah-lainnyasepakat-akhiri-psbb-surabaya-rayakhofifah?page=all\#page2 
dilakukan pada tnaggal 28 April 2020 dan berakhir hingga 11 Mei. Namun karena sampai tanggal 11 Mei jumlah kasus semakin banyak, maka PSBB di Surabaya Raya diperpanjang hingga 25 Mei dan diperpanjang ketiga kalinya berakhir pada tanggal 8 Juni 2020.

Pemberhentian PSBB di Surabaya memiliki pertimbangan yang cukup serius karena dilihat dari jumlah kasus positif COVID-19 di Jawa Timur. Dilihat dari laman resmi, jumlah kasus positif di Surabaya per Minggu (7/6/2020) mencapai 3124 jiwa terbanyak di Jawa Timur. ${ }^{8}$

Untuk informasi tentang perkembangan virus COVID19 ini, media berlomba-lomba dengan cepat memberikan informasi terbaru seputar kebijakan pemerintah untuk menanggulangi, update seputar jumlah orang yang terinfeksi virus setiap harinya. Banyak media mulai memberitakan beberapa perkembangan informasi kasus virus COVID19 ini dari Televisi, Radio, Koran, Youtube, Twitter, Instagram sampai di beberapa Portal berita online.Hal ini dimudahkan oleh berbagai kecanggihan teknologi, sehingga informasi mudah didapat hanya sekali sentuh pada layar handphone jika orang tersebut suka melihat berita melalui telepon pintar mereka. Bagi mereka yang kecil pengetahuan menggunakan telepon pintar mereka cukup mengganti kanal radio atau TV mereka untuk melihat infromasi.

Dari semua media yang disebutkan beberapa dari media tersebut pasti

${ }^{8}$ Jatimprov , "Data Pemantauan Covid-19 KOTA SURABAYA 7 Juni 2020, ” 7 Juni 7, 2020, (http://infocovid19.jatimprov.go.id/index.php/dat a. memiliki perfektif sendiri dalam menyikapi suatu kejadian. Banyak dari mereka mungkin pro dan juga kontra dalam beberapa keputusan yang dibuat oleh pemerintah dalam menangani virus corona ini. Dari perfektif yang berbeda itu, sorang wartawan bisa jadi menuangkan sedikit perfektif mereka didalam berita. Tidak semua wartawan akan merusak suatu isi berita hanya karena perfektif mereka yang bebeda, bisa jadi itu dijadikan ciri untuk portal berita online tersebut. Karena jika suatu portal berita online tidak memiliki ciri khusus dan perfektif yang berbeda pada berita yang ia tayangkan, akan membuat orang mungkin mengenyampingkan berita dari media online tersebut, karena orang akan berfikir untuk apa melihat berita yang dilihat dari judul atau headlinenya saja sama.

Banyak portal berita memberikan informasi yang mungkin dari portal berita A dengan portal berita $B$ memiliki kesamaan isi tetapi mereka membedakan hal tersebut dengan judul atau headline yang mereka buat. Namun tidak menutup kemungkinan juga untuk memiliki isi yang berbeda. Tidak hanya itu wartawan juga memiliki gaya penulisan mereka sendiri terhadap suatu berita yang akan di tulis. ${ }^{9}$ Seperti ada peristiwa yang diberitakan, ada yang tidak ingin diberitakan, ada beberapa aspek yang ingin ditonjolkan dan ada juga yang ingin dihilangkan. Semua hal itu mengarah ke sebuah konsep yang disebut framing. Dalam perspektif komunikasi, analisis framing dipakai untuk membedah

${ }^{9}$ Zainal Abidin Achmad, “ Sikap Masyarakat Muslim Pelaku Yoga di Surabaya Tentang Berita Fatwa MUI haramkan Yoga”, Jurnal Ilmu Komunikasi 1 no 2 (Juni, 2009), 111-120 
cara-cara atau ideologi media saat mengonstruksi fakta. ${ }^{10}$

Satu berita online yang juga memberitakan tentang COVID-19 adalah Kompas.com dan suarasurabaya.net. Kompas.com merupakan salah satu media online yang sudah ada sejak tahun 1995, dimana kompas memulai sebagai portal berita yang terpercaya di Indonesia. Kompas.com tidak hanya membuat berita dalam bentuk teks tetapi juga berbentuk gambar, vidio, hinggal live streaming. Wajar saja saat ini kompas.com menjadi salah satu situs media online yang paling diminati.

Sedangkan Suarasurabaya.net ialah portal berita yang telah ada sejak 1999, yang merupakan bagian dari Suara Surabaya media yang sudah ada sejak 11 Juni 1983. Media itu ialah radio Suara Surabaya, radio tersebut merupakan radio yang terkenal di kota Surabaya

Untuk dapat mengetahui bagaimana ketiga media online diatas membingkai pemberitaan tentang PSBB Surabaya Raya diberhentikan digunakan model analisis framing Zhong Dan Pan dan Gerald M. Kosicki dimana model ini dibagi menjadi 4 struktur, struktur sintaksis, struktur skrip, struktur tematik atau kohesi dan koherensi, struktur retoris atau penggunaan kata, idiom, gambar dan grafik.

${ }^{10}$ Alex Sobur, “Analisis Teks Media: Suatu Pengantar Analisis Wacana, Analisis Semiotik, dan Analisis Framing" (Bandung: PT Remaja Rosdakarya, 2015)

${ }^{11}$ Kumala Citra Somara Sinaga, "Analisis Framing Pemberitaan Bom Sarinah di kompas.com dan merdeka.com", (Surabaya: JOM FISIP, 2016): 5.

\section{Tinjauan Pustaka}

\section{Media Online}

Semakin berkembangnya teknologi saat ini telah melahirkan berbagai produk online, seperti televisi, koran dan radio online. Dengan teknologi internet yang semakin maju sehingga mempermudah akses ke berbagai situs yang tersedia. Online Media adalah tatanan baru yang terus mengalami perkembangan. ${ }^{11}$ Dijaman sekarang ini semua orang dimana saja dapat dengan mudah melihat televisi, membaca koran, dan mendengar radio secara online. Syarat untuk mempermudah itu juga memerlukan sebuah jaringan koneksi internet.

\section{Teori Representasi Media}

Teori Representasi (Theory of Representation) diperkenalkan oleh Hall (1997) menjadi teori utama untuk melakukan penelitian ini. Pada teori representasi fokus pada penggunaan bahasa (language) digunakan untuk menyampaikan sesuatu yang berarti (meaningful) kepada orang lain. Representasi adalah mengartikan konsep (concept) yang ada di pikiran kita dengan menggunakan Bahasa. ${ }^{12}$

Teori representasi sendiri dibagi dalam tiga pendekatan. ${ }^{13}$ Pertama, Reflective approach yang menjelaskan bahwa bahasa berfungsi seperti cermin yang merefleksikan arti yang sebenarnya.

${ }^{12} \mathrm{Al}$ Sukri dan Chelsy Yesicha, "Analisis Framing Berita Penangkapan Gubernur Riau Annas Maamun Di Surat Kabar Riau Pos dan Tribun Pekanbaru", Jurnal Komunikasi Global (2017): 224-226

${ }^{13}$ Struart Hall, "Representations and Signifying Practices" (London: Sage Publication and The Open University, 1997) 
Misalnya, Sayur ya berarti sayur, tidak ada arti lain. Yang kedua, Intentional approach, dimana bahasa digunakan mengekspresikan arti personal dari seseorang penulis atau pelukis untuk mengungkapkan pengertian yang unik melalui bantuan bahasa. Pendekatan ini di sisi lain menyebutkan bahwa esensi bahasa adalah berkomunikasi didasarkan pada kode-kode yang telah menjadi konvensi di masyarakat bukan kode pribadi. Dan yang ketiga, Constructionist approach yaitu pendekatan yang menggunakan bahasa (language) untuk merepresentasikan sebuag konsep.Sistemnya dikonstruksi melalui suara, gambar, dan hingga coretcoretan. Yang intinya lebih pada fungsi simbolik.

Dalam penelitian ini lebih menggunakan pendekatan constructionist approach, untuk pendekatan semiotic dan discursive tidak digunakan dalam penelitian ini karena kurang cocok dengan metode analisis yang digunakan yaitu framing. Relevansi utama dari teori constructionist didalam penelitian adalah tentang penjelasan bahwa bahasa (language) yang terdapat didalam berita berupa kumpulan dari signs (artikel, foto, video, kalimat) memiliki arti (meaning) dan dapat merepresentasikan budaya (culture) yang ada di masyarakat kita, termasuk media.

\section{Rekonstruksi Berita}

Pada setiap portal berita memiliki gayanya sendiri saat akan memuat berita,

\footnotetext{
${ }^{14}$ Alex Sobur, “ Analisis Teks Media: Suatu Pengantar Analisis Wacana, Analisis Semiotik, dan Analisis Framing" (Bandung: PT Remaja Rosdakarya, 2015), 88.
}

perbedaan dari setiap portal juga berpengaruh dari bagaimana cara penulis berita menggambarkan hasil wawancara yang mereka dapat dengan bahasa mereka sendiri. Disebabkan sifat dan faktanya bahwa pekerjaan media massa adalah menceritakan peristiwa-peristiwa, maka seluruh isi media adalah realitas yang telah dikonstruksikan (constructed reality). ${ }^{14}$ Rekonstruksi sesndiri sering diketahui sebagai pendekatan konstruksionis. Dalam pendekatan konstruksionis sendiri ada 2 karakteristik.

Karakteristik pertama, Pendekatan yang menekan pada politik pemaknaan dan proses bagaimana seseorang menggambarkan realitas tersebut. makna bukan sesuatu yang statik di temukan didalam suatu pesan. Dan kedua, Pendekatan konstruksionis memandang kegiatan proses secara dinamis. Pendekatan konstruksionis memeriksa bagaimana pemmbentuka pesan dari sisi komunikator dan dalam sisi penerima ia memeriksa bagaimana konstruksi makna individu ketika menerima pesan. Pesan dipandang bukan sebagai mirror of reality yang menampilkan fakta apa adanya. ${ }^{15}$

\section{Analisis Framinng}

Model analisis framing Pan dan Kosicki mendefinisikan bahwa framing adalah sebuah proses membuat suatu pesan lebih menonjol, menempatkan informasi lebih daripada yang lain sehingga khalayak lebih tertuju pada pesan tersebut. ${ }^{16}$ Zhongdan Pan dan Gerald M. Kosicki (1993) melalui tulisan mereka "Framing

\footnotetext{
${ }^{15}$ Eriyanto, “Analisis Framing: Konstruksi, Ideologi dan Politik Media” (Yogyakarta: Lkis Yogyakarta, 2009), 40-41.

${ }^{16}$ Eriyanto, Analisis Framing, 252
} 
Analysis: An Approach to News Discourse" mengoperasionalisasikan empat dimensi sturktural teks berita sebagai perangkat framing: sintaksis, skrip, tematik, dan retoris. ${ }^{17}$

Tabel 1: Kerangka Framing Pan dan Kosicki (Sobur 2015, 176)

\begin{tabular}{|c|c|c|}
\hline Struktur & $\begin{array}{l}\text { Perangkat } \\
\text { Framing }\end{array}$ & $\begin{array}{l}\text { Unit yang } \\
\text { diamati }\end{array}$ \\
\hline $\begin{array}{l}\text { SINTAKSIS } \\
\text { Cara } \\
\text { wartawan } \\
\text { menyusun } \\
\text { fakta }\end{array}$ & 1. Skema berita & $\begin{array}{l}\text { Headline, } \\
\text { lead, latar } \\
\text { informasi, } \\
\text { kutipan, } \\
\text { sumber, } \\
\text { pernyataan, } \\
\text { penutup }\end{array}$ \\
\hline $\begin{array}{l}\text { SKRIP } \\
\text { Cara } \\
\text { wartawan } \\
\text { mengisahkan } \\
\text { fakta }\end{array}$ & $\begin{array}{l}\text { 2. Kelengkapan } \\
\text { berita }\end{array}$ & $5 \mathrm{~W}+1 \mathrm{H}$ \\
\hline $\begin{array}{l}\text { TEMATIK } \\
\text { Cara } \\
\text { wartawan } \\
\text { menulis } \\
\text { fakta }\end{array}$ & 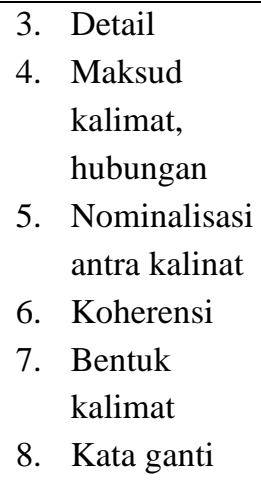 & $\begin{array}{l}\text { Paragraf, } \\
\text { proposisi }\end{array}$ \\
\hline $\begin{array}{l}\text { RETORIS } \\
\text { Cara } \\
\text { wartawan } \\
\text { menekankan } \\
\text { fakta }\end{array}$ & $\begin{array}{l}\text { 9. Leksikon } \\
\text { 10. Grafis } \\
\text { 11. Metafor } \\
\text { 12. Pengandaian }\end{array}$ & $\begin{array}{l}\text { Kata, idiom, } \\
\text { gambar/foto, } \\
\text { grafik }\end{array}$ \\
\hline
\end{tabular}

\footnotetext{
${ }^{17}$ Alex Sobur, “ Analisis Teks Media: Suatu Pengantar Analisis Wacana, Analisis Semiotik, dan Analisis Framing” (Bandung: PT Remaja Rosdakarya, 2015), 175.

${ }^{18}$ I Made Anom Wiranata dkk, "The Contestation of Discourses on Sustainable
}

\section{Metode Penelitian}

Jenis penelitian yang digunakan adalah penelitian kualitatif. Sifat penelitian ini adalah deskriptif analisis yang bertujuan untuk mendeskripsikan karakteristik pemberitaan di Kompas.com dan Suarasurabaya.net. Dalam analisis ini peneliti menggunakan analisis framing Zhong Dan Pan dan M. Kosicki, model ini berasumsi bahwa pada setiap berita mempunyai bingkai yang berfungsi dari organisasi ide. Framing berhubungan dengan makna, seperti memaknai suatu pertistiwa dilihat dari sebuah tanda yang dimunculkan dalam teks. ${ }^{18}$ Dengan menggunakan metode analisis framing Pan dan Kosicki yang diharapkan bisa membedah pemberitaan tentang pemberhentian PSBB Surabaya Raya. Data primer dalam penelitian ini diperoleh dari pemberitaan Kompas.com dan Suarasurabaya.net. Data sekunder merupakan data pendukung yang diperoleh dari sumber buku, internet, artikel, jurnal, dsb.

Pada penelitian ini pengambilan data diperoleh dengan mengunduh berita mengenai PSBB Surabaya Raya yang dimuat di portal berita Kompas.com dan Suarasurabaya.net pada berita tanggal 8 Juni 2020 - 9 Juni 2020 atau berita yang dimuat setelah ada wawancara bersama Gubernur Jawa Timur Khofifah Indar Parawansa mengenai keputusan beliau untuk tidak memperpanjang PSBB

Development in the Controversy of Benoa Bay Reclamation. In International Conference on Contemporary Social and Political Affair 2016. RE-EXAMINING GOVERNANCE: STRENGTHENING CITIZENSHIP IN THE CHANGING WORLD”, 2016. 
Surabaya Raya. ${ }^{19}$ Dari jam setelah Gubernur Jawa Timur tersebut diwawancarai terdapat 3 berita Kompas.com yang menyinggung berita tersebut, begitu juga dengan Suarasurabaya.net. pengambilan artikel berita tidak hanya berita yang diambil setelah Gubernur memberi pernyataan tetapi juga mengambil berita dengan judul yang berkaitan dengan pernyataan tersebut diluar dari segi jam.

Berdasarkan urutan tersebut urutan pertama dan kedua ditempati oleh detik.com dan kompas.com. Namun dalam penelitian ini peneliti memilih Kompas.com untuk dijadikan portal berita pertama yang akan dianalisis, kemudian untuk kedua peneliti ingin membandingkan dengan portal nasional dan peneliti memilih Radio surabaya namun menggunkaan versi web untuk digunakan yaitu suarasurabaya.net.

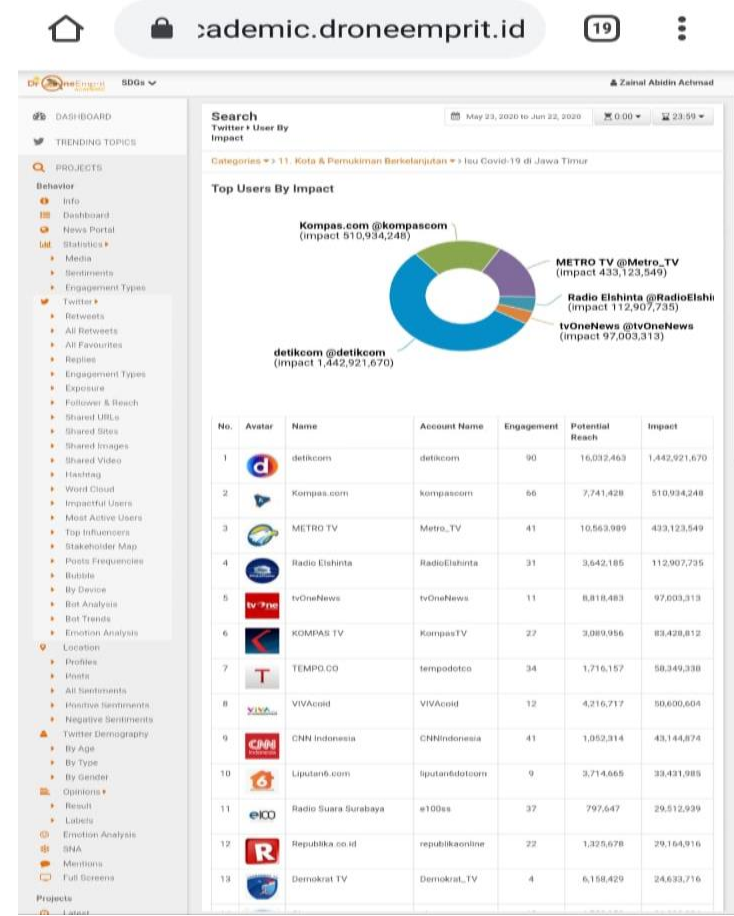

Gambar 2: Daftar user paling berpengaruh membahas isu Covid-19 (academic.droneemprit.id 2020)

Penelitian ini memunculkan hasil sebuah konstruksi seseorang yang di buat oleh sebuah berita maka peneliti juga memasukan hasil ekspos Gubernur di Jawa dan Walikota/Bupati di Jawa Timur yang didapat dari Indonesia Indicator periode 19 Juni 2020, untuk mengetahui apakah benar dari konstruksi yang di buat oleh berita tersebut juga masuk kedalam salah satu data yang ada di Indonesia Indicator.

\footnotetext{
${ }^{19}$ Khofifah Indar Parawansa, "Breaking News - PSBB Surabaya Raya Berakhir", Juli 1, 2020 , (https://www.youtube.com/watch?v=s2EE7HR43 Do
} 


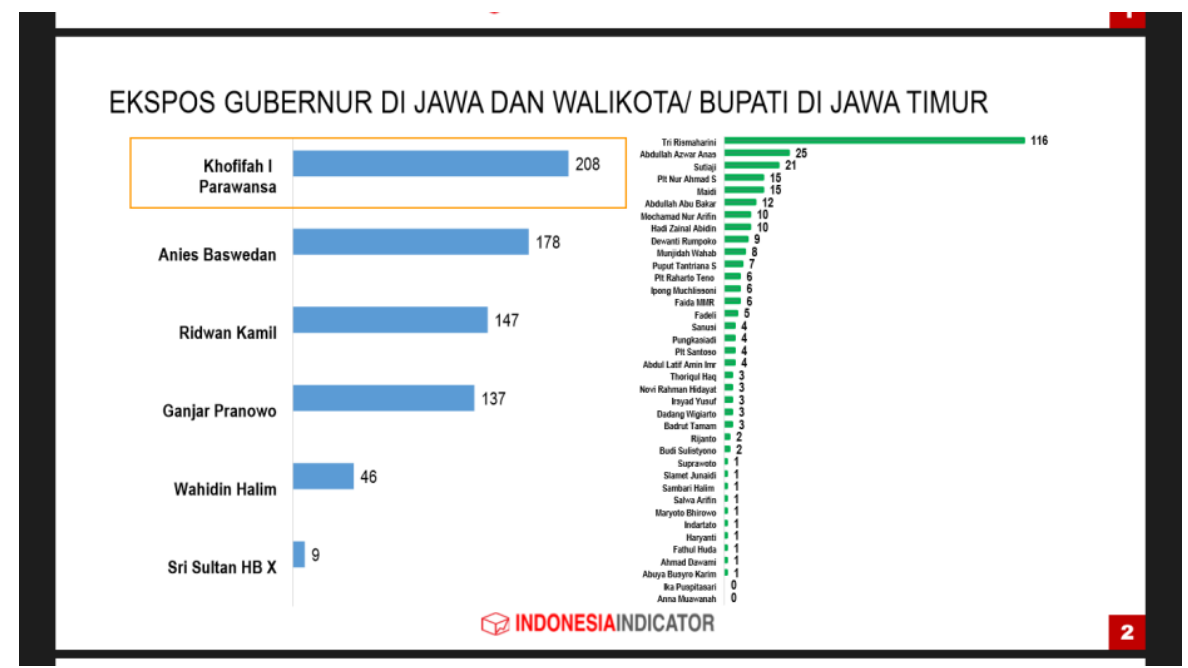

Gambar 3: Ekspos berita Covid-19 oleh pimpinan daerah Jawa Timur

(Sumber: Indonesia Indicator)

\section{Hasil dan Pembahasan}

Analisis framing ini dilakukan terhadap berita-berita yang dimuat oleh Kompas.com dan suarasurabaya.net terkait akan diberhentikannya PSBB Surabaya Raya. Adapun penyajiannya sesuai dengan waktu (kronologis) menjelang masa berakhirnya PSBB pada tanggal 8 Juni - 9 Juni 2020 atau yang dihitung saat sudah keluarnya keputusan dari Gubernur Jawa Timur Khofifah Indar Parawansa menyetujui untuk tidak memperpanjang PSBB Surabaya Raya.

\section{Analisis Berita 1}

Judul : Risma dan 2 Kepala Daerah Lainnya Sepakat Akhiri PSBB Surabaya Raya, Khofifah Fasilitator

Sumber : Kompas.com ${ }^{20}$ - 08/06/2020, 21:17 WIB

${ }^{20}$ Achmad Faizal, "Risma dan 2 Kepala Daetah Lainnya Sepakat Akhiri PSBB Surabaya Raya, Khofifah Fasilitator" Juni 22, 2020, (https://regional.kompas.com/read/2020/06/08/
Analisis :

1. Struktur Sintaksis

Judul dalam berita ini sedikit tidak pas terhadap isi berita, Nama Bu Khofifah disebut dalam Judul tersebut, namun didalam isi berita hanya sedkit menyinggung nama $\mathrm{Bu}$ Khofifah, bahkan tidak ada pernyataan resmi dari $\mathrm{Bu}$ Khofifah dalam berita tersebut. Latar informasinya lebih dari 1. Sumbernya yaitu merukan hasil wawancara bersama Heru Tjahjono yang saat itu sebagai Sekertaris Daerah Provinsi Jawa Timur. 21172681/risma-dan-2-kepala-daerah-lainnyasepakat-akhiri-psbb-surabaya-rayakhofifah?page=all\#page2 
2. Struktur Skrip

Tabel 2: Struktur Skrip (berita dari kompas.com berjudul Risma dan 2 Kepala

Daerah Lainnya Sepakat Akhiri PSBB

Surabaya Raya, Khofifah Fasilitator)

\begin{tabular}{|l|l|}
\hline \multicolumn{1}{|c|}{$\begin{array}{l}\text { Apa isi berita } \\
\text { tersebut? }\end{array}$} & $\begin{array}{c}\text { Kepala daerah } \\
\text { Surabaya Raya } \\
\text { sekapat untuk tak } \\
\text { melanjutkan PSBB } \\
\text { saat Rapat Evalusai } \\
\text { PSBB }\end{array}$ \\
\hline $\begin{array}{l}\text { Siapa yang memberi } \\
\text { pernyataan pada } \\
\text { berita tersebut? }\end{array}$ & $\begin{array}{l}\text { Kepala daerah } \\
\text { Surabaya Raya }\end{array}$ \\
\hline $\begin{array}{l}\text { Kapan rapat } \\
\text { evalusais } \\
\text { dilaksanakan? }\end{array}$ & Senin, 8 Juni 2020 \\
\hline $\begin{array}{l}\text { Dimana Tempat } \\
\text { Rapat tersebut? }\end{array}$ & $\begin{array}{l}\text { Gedung Negara } \\
\text { Grahadi }\end{array}$ \\
\hline $\begin{array}{l}\text { Mengapa Kepala } \\
\text { daerah sepakat untuk } \\
\text { tidak melanjutkan }\end{array}$ & $\begin{array}{l}\text { Permasalahan } \\
\text { ekonomi harus } \\
\text { PSBB ? }\end{array}$ \\
$\begin{array}{l}\text { tetap bergerak agar } \\
\text { dapat bertahan di } \\
\text { tengah pandemik }\end{array}$ \\
\hline $\begin{array}{l}\text { Bagaimana jika } \\
\text { PSBB tiidak } \\
\text { dilanjutkan? }\end{array}$ & $\begin{array}{l}\text { Pemkot Surabaya } \\
\text { sudah menyiapkan } \\
\text { protokol kesehatan } \\
\text { ketat yang harus } \\
\text { dilakukan } \\
\text { masyarakat jika } \\
\text { PSBB Surabaya tak } \\
\text { diperpanjang. }\end{array}$ \\
\hline
\end{tabular}

\section{Struktur Tematik}

Untuk penekanan fakta terdapat pada

kutipan hasil wawancara, yang pertama adalah kutipan dari heru Tjahjono.

$$
\begin{aligned}
& \text { "Gubernur Jawa Timur } \\
& \text { dalam hal ini hanya } \\
& \text { fasilitator saja," kata Heru } \\
& \text { usai rapat....." }
\end{aligned}
$$

Kata fasilitator disini menimbulkan dua makna, yang pertama Gubernur Jawa Timur menjadi Fasilitator yang dalam artian pendukung untuk kelanjutan rapat PSBB, atau menjadi fasilitator yaitu sebagai pendukung saat kegiatan new normal nanti. Lalu selanjutnya pada kutipan wawancara bersama Risma di Gelora Bung Tomo.

" "ini teman-teman lagi membahas hal itu. Mudahmudahan nanti bisa diterima usulann kita sama Bu Gubuernur." Kata Risma saat di temui di Gelora Bung Tomo, Surabaya, Minggu (7/6/2020)'

Kutipan ini membenarkan kalimat pada lead berita.

'.... keputusan tersebut

merupakan kesepakatann

kepala daerha di tiga

wilayah tersebut.'.

$\mathrm{Bu}$ Risma merupakan salah satu Walikota dari 3 Wilayah Surabaya Raya.

\section{Sturktur Retoris}

Jika sebelumnya pada bagian Struktur Sintaksis Bu Khofifah sedikit dibahas didalam isi berita, dan tidak sesuai dengan judul berita. Ini berbanding terbalik dengan Gambar untuk berita ini, gambar yang digunakan tepat dengan judul berita yaitu menampilkan sosok Bu Khofifah yang tepat didepannya berada sebuah mic menandakan ia sedang berada dalam ruang rapat. 


\section{Analisis Berita 2}

Judul : PSBB Surabaya Raya Belum Layak Diakhiri, Ini Alasan Ahli Epidemiologi

Sumber : Kompas.com ${ }^{21}{ }_{-} \quad$ 08/06/2020,

\section{2:13 WIB}

Analisis :

\section{Struktur Sintaksis}

Skema judul menunjukan bahwa Surabaya Raya masih belum cukup untuk melakukan New Normal berdasarkan ahli Epidemiologi. Headline sesuai dengan isi berita yang banyak mengutip dari wawancara bersama ahli Epidemiologi.

2. Struktur Skrip

Tabel 3: Struktur Skrip (berita dari kompas.com berjudul PSBB Suarabaya Raya Belum Layak Diakhiri, Ini Alasan Epidemiologi)

\begin{tabular}{|c|c|}
\hline $\begin{array}{l}\text { Apa isi berita } \\
\text { tersebut? }\end{array}$ & $\begin{array}{c}\text { Ahli Epidemiologi } \\
\text { mengatakan bahwa } \\
\text { Surabaya Raya } \\
\text { belum siap untuk } \\
\text { masuk New Normal. }\end{array}$ \\
\hline $\begin{array}{l}\text { Siapa yang } \\
\text { mengatakan } \\
\text { pernyataan } \\
\text { tersebut? }\end{array}$ & $\begin{array}{l}\text { Ahli Epidemiologi } \\
\text { Universitas } \\
\text { Airlangga Windhu } \\
\text { Purnomo. }\end{array}$ \\
\hline $\begin{array}{l}\text { Kapan dikatakan } \\
\text { pernyataan } \\
\text { tersebut? }\end{array}$ & Senin $(8 / 6 / 2020)$ \\
\hline $\begin{array}{l}\text { Dimana dikatakan } \\
\text { pernyataan } \\
\text { tersebut? }\end{array}$ & Surabaya \\
\hline
\end{tabular}

${ }^{21}$ Ghinan Salman, "Surabaya Raya Belum Layak Diakhiri Ini Alasan Epidemiologi”, Juni 22, 2020, https://regional.kompas.com/read/2020/06/08/2 2130181/psbb-surabaya-raya-belum-layakdiakhiri-ini-alasan-ahliepidemiologi?page=all\#page2

\begin{tabular}{|l|l|}
\hline \multicolumn{1}{|c|}{$\begin{array}{c}\text { Apa isi berita } \\
\text { tersebut ? }\end{array}$} & $\begin{array}{l}\text { Ahli Epidemiologi } \\
\text { mengatakan bahwa } \\
\text { Surabaya Raya } \\
\text { belum siap untuk } \\
\text { masuk New Normal. }\end{array}$ \\
\hline $\begin{array}{l}\text { Mengapa PSBB } \\
\text { Surabaya Raya } \\
\text { masih belum } \\
\text { layak diakhiri? }\end{array}$ & $\begin{array}{l}\text { Berdasarkan riset } \\
\text { yang dilakukan } \\
\text { Fakultas Kesehatan } \\
\text { Masyarakat (FKM) } \\
\text { Unair masyarakat di } \\
\text { wilayah Surabaya } \\
\text { Raya dinilai tidak } \\
\text { peduli denga } \\
\text { protokol. }\end{array}$ \\
\hline $\begin{array}{l}\text { Bagaimana } \\
\text { pendapat ahli } \\
\text { Epidemiologi ? }\end{array}$ & $\begin{array}{l}\text { Perilaku masyarakat } \\
\text { makin memburuk di } \\
\text { tengah PSBB } \\
\text { semakin banyak } \\
\text { yang tidak memakai } \\
\text { masker. }\end{array}$ \\
\hline
\end{tabular}

\section{Struktur Tematik}

Kompas.com

untuk memperkuat berita mengutip pernyataan dari ahli Epidemiologi. Seperti kata-kata berikut : diperlonggar, dibongkar, enggak karuan, makin memburuk, kita harus, lonjakan kasus.

\section{Struktur Retoris}

Berdasarkan kata-kata yang didapat pada struktur tematik, katakata tersebut sangat menekankan pada bagian Judul bahwa Surabaya Raya belum layak di akhiri dan sikap 
masyarakat yang acuh terhadap peraturan. Seperti :
' "Tidak diperlonggar
saja, sekarang sudah
kayak gini. Dibongkar
(dilonggarkan) tambah
enggak karuan
(berantakan)" kata
Windhu saat dihubungi
di Surabaya'

Kata diperlonggar, longgar sendiri menurut KBBI ialah tidak ketat mengartikan tidak diketatkannya peraturan. Dibongkar pun sama artinya dengan diperlonggar. Untuk kalimat enggak karuan diartikan berantakan, kasus positif makin banyak dan terus bertambah di setiap wilayah.

"Bapenas sudah kasih pedoman, kita harus nurut itu sesuai dengan WHO,..."

Kata kita harus nurut, dimaksudkan kita harus menaati aturan yang sudah diberikan.
‘ "Karena yang kami
khawatirkan lonjakan
kasus, jadi enggak perlu
buru- buru (mengakkhiri
PSBB)" ujar dia'

Kata lonjakan kasus mengarahkan bahwa kasusnya semakin bertambah dan belum waktunya mengakhiri PSBB. Berdasarkan gambar cocok dengan isi beritanya.

${ }^{22}$ Antara, "SBB Surabaya Raya Berakhir, Risma : Ini Lebih Berat, Kita Tidak Boleh Lengah dan Sembrono", Juni 22, 2020, (https://regional.kompas.com/read/2020/06/09/

\section{Analisis Berita 3}

Judul : PSBB Surabaya Berakhir, Risma : Ini Lebih Berat, Kita Tidak Boleh Lengah dan Sembrono

Sumber : Kompas.com ${ }^{22}-\quad$ 09/06/2020, 06:33 WIB

Analisis :

1. Struktur Sintaksis

Pada berita ini menjelaskan harapan dari tokoh utama berita tersebut. Mendiskripsikan Wali Kota Surabaya Tri Rismaharini meminta warganya lebih disiplin menerapkan protokol kesehatan setelah PSBB, sesuai dengan Judulnya "Risma : Ini lebih berat, kita tidak boleh lengah dan sembrono."

2. Struktur Skrip

Tabel 3: Struktur Skrip (berita dari

kompas.com berjudul PSBB Surabaya

Berakhir, Risma : Ini Lebih Berat, Kita Tidak Boleh Lengah)

\begin{tabular}{|l|l|}
\hline \multicolumn{1}{|c|}{$\begin{array}{c}\text { Apa isi berita } \\
\text { tersebut } ?\end{array}$} & \multicolumn{1}{|c|}{$\begin{array}{c}\text { Harapan risma } \\
\text { terhadap warga } \\
\text { Surabaya untuk } \\
\text { setelah PSBB }\end{array}$} \\
\hline $\begin{array}{l}\text { Siapa yang } \\
\text { mengatakan } \\
\text { pernyataan } \\
\text { tersebut? }\end{array}$ & $\begin{array}{l}\text { Wali kota Surabaya } \\
\text { Tri Risma Harini }\end{array}$ \\
\hline $\begin{array}{l}\text { Kapan dikatakan } \\
\text { pernyataan } \\
\text { tersebut? }\end{array}$ & $\begin{array}{l}\text { Senin malam } \\
(8 / 6 / 2020)\end{array}$ \\
\hline $\begin{array}{l}\text { Dimana dikatakan } \\
\text { pernyataan } \\
\text { tersebut? }\end{array}$ & Di rumah dinasnya \\
\hline
\end{tabular}

06330041/psbb-surabaya-raya-berakhir-risma-inilebih-berat-kita-tidak-bolehlengah?page=all\#page2 . 


\begin{tabular}{|l|l|}
\hline \multicolumn{1}{|c|}{$\begin{array}{c}\text { Apa isi berita } \\
\text { tersebut? }\end{array}$} & \multicolumn{1}{|c|}{$\begin{array}{c}\text { Harapan risma } \\
\text { terhadap warga } \\
\text { Surabaya untuk } \\
\text { setelah PSBB }\end{array}$} \\
\hline $\begin{array}{l}\text { Mengapa PSBB } \\
\text { diakhiri? }\end{array}$ & $\begin{array}{l}\text { PSBB diakhiri untuk } \\
\text { memudahkan } \\
\text { warganya mencari } \\
\text { mata pencaharian }\end{array}$ \\
\hline $\begin{array}{l}\text { Bagaimana } \\
\text { harapan walikota } \\
\text { Surabaya? }\end{array}$ & $\begin{array}{l}\text { Meminta warga kota } \\
\text { Surabaya dan } \\
\text { meminta pihak } \\
\text { hotel, restoran, mal, } \\
\text { pertokoan, dan pasar } \\
\text { disiplin menerapkan } \\
\text { protokol kesehatan. }\end{array}$ \\
\hline
\end{tabular}

\section{Struktur Tematik}

Kompas menegaskan untuk judul yang dipasang tentang harapan walikota Surabaya. Dan untuk meningkatkan pembaca dengan mengambil kutipan, dengan kata sebagai berikut : kita harus jaga kepercayaan itu dan tidak boleh sembrono, tidak boleh lengah dan sembrono, kita harus selalu disiplin, sekali lagi ini amanah.

\section{Struktur Retoris}

Berdasarkan kata-kata tersebut yang didapat pada struktur tematik, kata-kata tersebut dengan maksud menekankan keinginan walikota Surabaya dengan beberapa pernyataan dari walikota Surabaya. Seperti pada kata :

، "Kalau kemarin banyak yang mengeluh ke saya ingin kehidupan normal, tapi dengan protokol kesehatan ketat. Ayo kita lakukan. Kita harus jaga kepercayaan itu dan tidak boleh sembrono,"

kata Risma saat menggelar jumpa pers,'

Kata kita harus jaga kepercayaan ditujukan keapada warga Surabaya untuk melakukan protokol kesehatan ketat. Lalu juga pada kata.

، "Ini justru malah lebih

berat karena di pundak kita terdapat kepercayaan, ayo kita jaga. Tidak boleh lengah dan sembrono," ujarnya.'

Kata sembrono diulang pada kutipan walikota Surabaya, itu mengartikan bahwa warga Surabaya tidak boleh seenaknya tidak melakukan protokol kesehatan saat PSBB Surabaya berakhir.

"Kita harus selalu disiplin, tolong ini diperhatikan..."

Kutipan $\mathrm{Bu}$ Risma di tunjukan kembali didalam berita dengan maksud juga mengingatkan pembaca. Tentang saat nanti juka ada protokol atau aturan baruu kita harus dengan sukarela menaatinya dan melakukannya.

"Sekali lagi, ini amanah bagi warga Surabaya..."

Kata amanah dipakai, amanah sendiri di KBBI diartikan sesuatu yang dipercayakan (dititipkan) kepada orang lain, ditambah lagi dengan kata sekali lagi, itu menunjukan Bu Risma sangat mengharapkan kepercayaan yang sudah di berikan untuk warga Surabaya. 


\section{Analisis Berita 4}

Judul : PSBB Surabaya Raya Tidak Diperpanjang

Sumber : suarasurabaya.net ${ }^{23}-8$ Juni 2020, 20.30 WIB

Analisis :

\section{Struktur Sintaksis}

Isi berita yang jelas sesuai dengan judul. Pada bagain leadnya menuliskan tentang Heru sebagai Sekertaris Gugus Tugas Covid-19 mengatakan hasil keputusan Rapat Evaluasi PSBB Surabaya Raya pada malam itu.

2. Struktur Skrip

Tabel 5: Struktur Skrip (berita dari kompas.com berjudul PSBB Surabaya Raya Tidak Diperpanjang)

\begin{tabular}{|c|c|}
\hline Apa isi berita tersebut? & $\begin{array}{c}\text { Hasil rapat } \\
\text { evaluasi PSBB } \\
\text { Surabaya Raya }\end{array}$ \\
\hline $\begin{array}{l}\text { Siapa yang memberikan } \\
\text { pernyataan tersebut? }\end{array}$ & Heru Tjahjono \\
\hline $\begin{array}{l}\text { Kapan memberikan } \\
\text { pernyataan tersebut? }\end{array}$ & Senin $(8 / 6 / 2020)$ \\
\hline $\begin{array}{l}\text { Dimana memberikan } \\
\text { pernyataan tersebut? }\end{array}$ & $\begin{array}{l}\text { Gedung Negara } \\
\text { Grahadi Surabaya }\end{array}$ \\
\hline $\begin{array}{l}\text { Mengapa PSBB } \\
\text { Surabaya } \\
\text { diberhentikan? }\end{array}$ & - \\
\hline $\begin{array}{l}\text { Bagaimana keputusan } \\
\text { PSBB Surabaya } \\
\text { diberhentikan? }\end{array}$ & \begin{tabular}{lr}
\multicolumn{2}{l}{ Keputusannya } \\
diambil & sendiri \\
oleh 3 & kepala \\
daerah & Surabaya \\
Raya &
\end{tabular} \\
\hline
\end{tabular}

3. Struktur Tematik

Isi beritanya dijelaskann dengan beberapa kutipan/ kalimat langsung dan kalimat tidak langsung.

${ }^{23}$ Denza Perdana, "PSBB Surabaya Tidak Diperpanjang”, Juni 22, 2020, (https://www.suarasurabaya.net/kelanakota/202 0/psbb-surabaya-raya-tidak-diperpanjang/
Kutipannya lebih menjelaskan siapa yang memiliki dan menginginkan PSBB tidak diperpanjang. Berikut kata-kata yanng menjelaskan isi berita yang dimaksud oleh peneliti : menegaskan, perlu dicatat, hanya berlaku sebagai mediator.

4. Struktur Retoris

"Heru Tjahjono Sekretaris

Gugus Tugas Covid-19

menegaskan, keputusan

tentang itu diambil oleh

masing-masing kepala

daerah, bukan oleh

Gubernur Jatim"

Kata menegaskan yang ditulis berita itu dengan kata lain menyakinkan wartawan.

"Sore tadi Pak Bupati

Gresik, Bupati Sidoarjo, juga Ibu Wali Kota Surabaya memutuskan tidak melanjutkan PSBB di Surabaya Raya. Perlu dicatat, yang memutuskan bukan provinsi, ya," ujarnya.'

Kata-kata hasil keputusan tersebut diperkuat dengan kata perlu dicatat untuk menegaskan kembali kepada wartawan. Tidak hanya sampai disitu penegasan yang dilakukan oleh sekertaris rapat tersebut tetapi penulis berita menulisnya dengan bentuk kalimat tidak langsung.

'Khofifah Indar Parawansa

Gubernur Jatim dalam 


proses $r$ terkait
keputusan
berakhirnya masa PSBB
Surabaya Raya tahap
ketiga pada 8 Juni ini,
hanya berlaku sebagai
mediator.'

\section{Analisis Berita 5}

$\begin{array}{ll}\text { Judul } & \text { Risma : Kalau Mau New } \\ & \text { Normal, Ayo Disiplin } \\ & \text { Protokol }\end{array}$

Sumber : suarasurabaya.net ${ }^{24}-8$ Juni 2020, 21.17 WIB

Analisis :

\section{Struktur Sintaksis}

Lead pada isi beritanya mejelaskan denga aik apa yang nantinya kaan dibahas di paragraf selanjutnya. Pada leadnya, Risma Ingin warga Surabaya untuk disiplin pada protokol yang dibuat saat PSBB tidak diperpanjang nanti.

\section{Struktur Skrip}

Tabel 6: Struktur Skrip (berita dari kompas.com berjudul Risma : Kalau Mau New Normal, Ayo Disiplin Protokol)

\begin{tabular}{|l|l|}
\hline $\begin{array}{c}\text { Apa isi berita } \\
\text { tersebut? }\end{array}$ & $\begin{array}{c}\text { Risma akan mengatur } \\
\text { protokol ketat dan detail } \\
\text { bagi berbagai lini usaha } \\
\text { dan aktivitas warga } \\
\text { ditengah transisi } \text { new } \\
\text { normal ini. }\end{array}$ \\
\hline $\begin{array}{l}\text { Siapa yang } \\
\text { memberikan } \\
\text { pernyataan ? }\end{array}$ & Risma \\
\hline $\begin{array}{l}\text { Kapan } \\
\text { memberikan } \\
\text { pernyataan } \\
\text { tersebut } ?\end{array}$ & Senin $(8 / 6 / 2020)$ malam. \\
\hline
\end{tabular}

${ }^{24}$ Zumrotul Abidin, "Risma: Kalau Mau New Normal, Ayo Disiplin Protokol." Juni 22, 2020, (https://www.suarasurabaya.net/kelanakota/202

\begin{tabular}{|l|l|}
\hline \multicolumn{1}{|c|}{$\begin{array}{c}\text { Apa isi berita } \\
\text { tersebut } ?\end{array}$} & $\begin{array}{c}\text { Risma akan mengatur } \\
\text { protokol ketat dan detail } \\
\text { bagi berbagai lini usaha } \\
\text { dan aktivitas warga } \\
\text { ditengah transisi } \text { new } \\
\text { normal ini. }\end{array}$ \\
\hline $\begin{array}{l}\text { Dimana } \\
\text { memberikan } \\
\text { pernyataan } \\
\text { tersebut ? }\end{array}$ & $\begin{array}{l}\text { Di Rumah Dinasnya } \\
\text { Jalan Sedap Malam. }\end{array}$ \\
\hline $\begin{array}{l}\text { Mengapa perlu } \\
\text { disiplin protokol } ?\end{array}$ & $\begin{array}{l}\text { Untuk menghadapi New } \\
\text { Normal dan mencegah } \\
\text { menambahnya jumlah } \\
\text { kasus. }\end{array}$ \\
\hline $\begin{array}{l}\text { Bagaimana } \\
\text { bentuk disiplin } \\
\text { protokol tersebut? }\end{array}$ & $\begin{array}{l}\text { Saat dimal jika penuh } \\
\text { jangan masuk dahulu, } \\
\text { menjaga jarak, wajib } \\
\text { hukumnya menggunakan } \\
\text { masker, harus cuci } \\
\text { tangan. }\end{array}$ \\
\hline
\end{tabular}

3. Struktur Tematik

Dari kutipan yang dimasukan oleh penulis berita didalam berita ini, menunjukan keinginan $\mathrm{Bu}$ Risma. Yang ditulis dengan kata sebagai berikut : Saya ingin, saya minta, ayo kita jaga, ini lah yang bahaya, mari kita.

\section{Struktur Retoris}

Dari kata yang disebutkan didalam struktur sebelumnya menjelaskan atau memaknai sebagai berikut :

"Saya ingin sampaikan kepada warga Surabaya bahwa kepercayaan dari Gubernur dan Forpimda Jatim ini kita tidak boleh ceroboh. Kalau kemarin banyak yang mengeluh ke saya ingin kehidupan normal tapi

0/risma-kalau-mau-new-normal-ayo-disiplinprotokol/ 
dengan protokol kesehatan ketat, ayo kita lakukan. Kita harus jaga kepercayaan itu, kita harus jaga semuanya, kita tidak boleh sembrono karena yang bisa jaga diri kita itu kita, bukan orang lain," ujar Risma' " "Saya minta seluruhnya, hotel, restoran, mal, pertokoan, perdagangan, pasar semuanya saja termasuk bengkel dan kontruksi. Ayo kita jaga, kita buktikan bahwa kita warga surabaya yang menghormati dan mentaati protokol yang sudah dibuat oleh pemerintah," kata Risma.'

"Mari kita semua taati peraturan, tidak boleh rea reo, tidak boleh seolah-olah lepas. Tidak boleh, tetap harus disiplin, tolong ini. Karena kepercayaan itu berat. Tidak bisa merasa diri kita bebas, ini belum selesai, masih banyak saudara-saudara kita yang di RS, masih banyak petugas medis berjuang yang menyembuhkan saudara kita yang ada di RS karena itu jangan ditambah lagi dengan kita tidak disiplin," ujarnya.'

Kata yang peneliti cetak miring dalam kutipan tersebut kalimat menunjukan ajakan dan harapan Bu Risma untuk warga Surabaya agar hati-hati, taati peraturan.

${ }^{25}$ Ika Suryani Syarief, "Publik Harus Patuh dan Berubah, di Tempat Keramaian Masih Banyak Pelanggar Protokol Kesehatan”, Juni 22, 2020,

\section{Analisis Berita 6}

Judul : Publik Harus Patuh dan Berubah, di Tempat Keramaian Masih Banyak Pelanggaran Protokol Kesehatan

Sumber : suarasurabaya.net ${ }^{25} \quad-9$ Juni $2020,13: 14$

Analisis :

\section{Struktur Sintaksis}

Pada bagian judul cukup tegas dan mengundang pembaca untuk mengetahui siapa yang mengatakan hal pada bagian judul tersebut. Leadnya menjelaskan dengan baik ,yaitu Kajian Heru tentang tempat yang ramai dikunjungi dann tidak mematuhi aturan/ protokol saat PSBB.

\section{Struktur Skrip}

Tabel 7: Struktur Skrip (berita dari

kompas.com berjudul Publik Harus

Patuh dan Berubah, di Tempat

Keramaian Masih Banyak Pelanggaran Protokol Kesehatan)

\begin{tabular}{|l|l|}
\hline Apa isi berita tersebut? & $\begin{array}{c}\text { Membahas aturan } \\
\text { dan beberapa dasar } \\
\text { untuk walikota } \\
\text { ketika membuat } \\
\text { protokol new } \\
\text { normal }\end{array}$ \\
\hline $\begin{array}{l}\text { Siapa yang memberi } \\
\text { pernyataan? }\end{array}$ & Heru \\
\hline $\begin{array}{l}\text { Kapan memberikan } \\
\text { pernyataan tersebut? }\end{array}$ & Selasa, 9 Juni 2020 \\
\hline $\begin{array}{l}\text { Dimana pernyataan } \\
\text { tersebut diberikan? }\end{array}$ & - \\
\hline $\begin{array}{l}\text { Mengapa 5 tempat } \\
\text { tersebut ramai dan } \\
\text { tidak menerapkan } \\
\text { protokol ? }\end{array}$ & - \\
\hline $\begin{array}{l}\text { Bagaimana bentuk } \\
\text { protokol yang akan } \\
\text { dibuat? }\end{array}$ & - \\
\hline
\end{tabular}

(https://www.suarasurabaya.net/kelanakota/202 0/aturan-transisi-new-normal-pertimbangkanhasil-kajian/ 


\section{Struktur Tematik}

Kata-kata yang dikutip cocok dengan judul, mengarah tentang protokol nantinya dan tempat ramai yang disebutkan dalam berita tersebut. Seperti kata-kata : tidak menerapkan, pakta integritas, patuh dan disipilin .

\section{Struktur Retoris}

“"Tempat

kursus/kampus/sekolah yang

masih aktif sebanyak 16,9

persen. Dari yang aktif itu, 75

persen tidak pakai masker dan

80

persen

tidak

menerapkan physical

distancing. Tempat ibadah

juga begitu, tapi sampai

sekarang tempat ibadah terus

berbenah, manata, dan terus

berubah," ujarnya

kepada Radio Suara Surabaya.

Kata dicetak miring tidak menerapkan, mengarah bahwa protokol nantinya yang dibuatdiharapkan warga dapat menerapkan physical distancing. Lalu berikutnya.

‘ "Jam 12 Gresik dulu, lalu Sidoarjo, terakhir Surabaya. Malam nanti ada pakta integritas yang kita susun," kata Heru.'

Lalu pada kutipan milik Heru, kata pakta sendiri menurut KBBI adalah perjanjian internasional. Yang maksud dari kalimat tersebut hari itu juga nanti secara bergantian akan menyusun penjanjian bersama pemerintahan Kota Surabaya, kabupaten Sidoarjo, dan Kabupaten
Gresik. Selanjutnya juga harapan Heru untuk masyarakat bekerjasama menjaga kesehatan dan mencegah bersama-sama dari virus Covid-19.

$\begin{array}{lr}\text { "'Patuh dan disiplin } \\ \text { menjaga } & \text { kesehatan, } \\ \text { memakai } & \text { masker, } \\ \text { dan physical } & \\ \text { distancing itu vaksin," } \\ \text { kata Heru.' }\end{array}$

Kata patuh dan disiplin tersebut menjelaskan keinginan Heru.

\section{Kesimpulan}

Dari analisis framing mengenai berita pemberhentian PSBB Surabaya Raya di media onlie Kompas.com dan Suarasurabaya.net yang telah dilakukan maka dapat ditarik kesimpulan sebagai berikut :

1. Struktur sintaksis; beberapa berita yang dianalisis dari kedua portal berita tersebut judul berita benar menggambarkan isi beritanya, memiliki banyak latar informasi dan sumber. Pada lead berita ada satu berita yag kurang sesuai dengan headline, yaitu pada analisis berita 1. Struktur berita; deadline umumnya memberikan nama media massa, tempat peristiwa dan tanggal kejadinnya. Kebanyakan dari berita mencukupi tiga unsur deadline berita tersebut, namun biasanya, unsur tempat peristiwa diletakkan pada bagian foto/gambar berita. Penelitian tiga dari enam berita tersebut menambahkan tempat peristiwa tersebut. Struktur skrip; banyak berita yang dianalisis memenuhi unsur $5 \mathrm{~W}+1 \mathrm{H}$ (What, Who, When, Where, Why, How), namun ada 
1-2 berita yang meninggalkan unsur tersebut, dan banyak ditemukan di berita suarasurabaya.net.

2. Struktur tematik; keduanya sama-sama menekankan dan memberitahukan lebih tentang berita yang mengarah kekhawatiran pemerintahan jika PSBB diberhentikan. Pada suarasurabaya.net, beberapa kutipannya memberi penekanan bahwa Gubernur Jawa Timur hanya sebagai mediator. Pada kompas.com isi beritanya lebih dapat dipertanggungjawabkan karena mereka membuat satu berita tentang PSBB Surabaya Raya apakah layak untuk diakhiri dengan hasil wawancara bersama seorang ahli epidemiologi yang telah melakukan riset sebelumnya. Sedangkan suarasurabaya.net memberitahukan informasi tentang banyaknya warga yang masih melanggar protokol hanya melalui telepon bersama Heru Tjahjono, seorang sekertaris gugus tugas Covid19.

3. Struktur retoris; kebanyakan dari berita yang dianalisis memiliki gambar yang sesuai dengan isi berita. Hanya satu gambar yang tidak memiliki kecocokan, yaitu pada berita analisis 1. Judul dengan gambar memiliki kecocokan, 'Risma dan dua Kepala Daerah Lainnya sepakat Akhiri PSBB Surabaya Raya, Khofifah Fasilitator'. Dalam judul tersebut orang akan berpikir apa yang dikatakan oleh $\mathrm{Bu}$ Khofifah mengenai hal tersebut, karena penekanan judul yang ada di bagian akhir dan diperkuat oleh gambar Bu Khofifah. Namun isi berita bukan hasil wawancara bersama
$\mathrm{Bu}$ Khofifah melainkan bersama Heru Tjahjono. Kutipan dari Heru Tjahjono tersebut yang dimuat untuk isi berita tersebut, yang mengatakan "Gubernur Jawa timur dalam hal ini hanya fasilitator saja" Heru Tjahjono sendiri selaku Sekertaris gugus Covid-19 yang mengikuti rapat evaluasi PSBB Surabaya Raya.

4. Penggunaan perbedaan kosakata juga terlihat dalam kedua portal berita ini, kompas.com menggunakan kata yang berbeda untuk mengatakan bahwa dalam rapat evaluasi Khofifah sebagai Gubernur Jawa Timur hanya dapat membantu. Kompas.com menggunakan kata fasilitator, sedangkan suarasurabaya.net menggunakan kata mediator. Fasilitator dalam KBBI ialah orang yang menyediakan fasilitas atau juga dapat dikatakan sebagai pendukung. Mediator dalam KBBI ialah perantara; penengah, orang yang bertindak sebagai - bagi pihak yang bersengketa. Menggunakan kata yang berbeda namun jika dipahami artinya Gubernur sebagai orang yang netral dalam hal ini atau tidak lagi berpihak dan akan menuruti apa yang diinginkan keputusan apa yang sedang diinginkan.

5. Segi konstruksi; suarasurabaya.net lebih menkonstruksi sosok dari Gubernur Jawa Timur sebagai orang yang kurang setuju dengan pemberhentian PSBB ini dilihat dari banyak kutipan Heru yang banyak menekankan bahwa keputusan yang dibuat ialah keputusan dari para walikota tiga area Surabaya Raya dan kosakata yang sebelumnya juga telah dibahas. 


\section{Daftar Pustaka}

Abidin, Zumrotul. 2020. Risma: Kalau Mau New Normal, Ayo Disiplin Protokol. 8 Juni. Diakses Juni 22, 2020.

https://www.suarasurabaya.net/kel anakota/2020/risma-kalau-maunew-normal-ayo-disiplinprotokol/.

academic.droneemprit.id. 2020. Twitter

Top Users by Impact, Isu Covid-19

Di jawa Timur. 7 Juni. Diakses

Juni 7, 2020.

https://academic.droneemprit.id//search/view/analysis/twitter/sub/u ser_by_impact/id/838.

Achmad, Zainal Abidin. 2009. Sikap Masyrakat Muslim Pelaku Yoga Di Surabaya Tentang Berita Fatwa MUI haramkan Yoga. Vol. 1. 2 vol. Surabaya: Jurnal Ilmu Komunikasi.

Antara. 2020. PSBB Surabaya Raya Berakhir, Risma : Ini Lebih Berat, Kita Tidak Boleh Lengah dan Sembrono. Disunting oleh Dheri Agriesta. 9 Juni. Diakses Juni 22, 2020.

https://regional.kompas.com/read/ 2020/06/09/06330041/psbbsurabaya-raya-berakhir-risma-inilebih-berat-kita-tidak-bolehlengah?page=all\#page2 .

Ariefana, Pebriansyah. 2020. Data 65 Warga Jawa Timur Suspect Virus Corona, Ini Penjelasan Dinkes. 5 Maret. Diakses Juni 15, 2020. https://jatim.suara.com/read/2020/ 03/05/140546/data-65-wargajawa-timur-suspect-virus-coronaini-penjelasan-dinkes diakses pukul 20.53.

Eriyanto. 2009. Analsis Framing:

Konstruksi, Ideologi dan Politik

Media. Yogyakarta: Lkis

Yogyakarta.

Faizal, Achmad. 2020. Risma dan 2 Kepala Daetah Lainnya Sepakat Akhiri PSBB Surabaya Raya, Khofifah Fasilitator. 8 Juni.

Diakses Juni 22, 2020. https://regional.kompas.com/read/ 2020/06/08/21172681/risma-dan2-kepala-daerah-lainnya-sepakatakhiri-psbb-surabaya-rayakhofifah?page=all\#page2 .

—. 2020. Surabaya, Gresik, dan Sidoarjo Sepakat Segera Berlakukan PSBB. Disunting oleh Aprillia Ika. 19 Apriil. Diakses Juni 15, 2020. https://surabaya.kompas.com/read/ 2020/04/19/19500911/surabayagresik-dan-sidoarjo-sepakatsegera-berlakukan-psbb? page=all .

Hall, Sturart. 1997. Representations and Signifying Practices. Disunting oleh Stuart Hall. London: Sage Publications and The Open University.

infocovid19.jatimprov.go.id. 2020. Data Pemantauan Covid-19 KOTA SURABAYA. 7 Juni. Diakses Juni 7, 2020. http://infocovid19.jatimprov.go.id/ index.php/data. 
Kemlu RI. 2020. Pernyataan Pers Kemlu tentang Update Pemulangan WNI dari Wuhan serta Kebijakan Pemri mengenai Pendatang/Traveler dari RRT. 2 Februari. Diakses Juli 1, 2020.

https://kemlu.go.id/portal/id/read/1 128/siaran_pers/pernyataan-perskemlu-tentang-updatepemulangan-wni-dari-wuhanserta-kebijakan-pemri-mengenaipendatangtraveler-dari-rrt.

Lova, Chyntia. 2020. PSBB Jakarta Mulai 10 April: Belajar Tetap di Rumah, Fasilitas Umum Ditutup. 7 April. Diakses Juli 1, 2020. https://megapolitan.kompas.com/re ad/2020/04/07/21552791/psbbjakarta-mulai-10-april-belajartetap-di-rumah-fasilitas-umumditutup.

Paranwansa, Khofifah Indar, wawancara oleh Kompas TV. 2020. BREAKING NEWS - PSBB Surabaya Raya Berakhir https://www.youtube.com/watch?v $=\mathrm{s} 2 \mathrm{EE} 7 \mathrm{HR}$ 43Do.

Perdana, Denza. 2020. PSBB Surabaya

Tidak Diperpanjang. 8 Juni.

Diakses Juni 22, 2020. https://www.suarasurabaya.net/kel anakota/2020/psbb-surabaya-rayatidak-diperpanjang/.

Salman, Ghinan. 2020. Surabaya Raya Belum Layak Diakhiri Ini Alasan Epidemiologi. Disunting oleh Dheri Agriesta. 8 Juni. Diakses Juni 22, 2020. https://regional.kompas.com/read/ 2020/06/08/22130181/psbbsurabaya-raya-belum-layakdiakhiri-ini-alasan-ahliepidemiologi?page=all\#page2 .

Sekretariat Presiden. 2020. "Live: Keterangan Pers Juru Bicara Covid-19 Pkl. 13.00, 12 Maret 2020.” Diakses Juli 01, 2020. https://www.youtube.com/watch?v $=$ EVoQIdXAx4g.

Sinaga, Kumala Citra Somara. 2016.

"ANALISIS FRAMING PEMBERITAAN BOM SARINAH DI KOMPAS.COM DAN MERDEKA.COM." JOM FISIP 5.

Sobur, Alex. 2015. Analisis Teks Media : Suatu Pengantar Analisis Wacana, Analisis Semiotik, dan Analisis Framing. Bandung: PT Remaja Rosdakarya.

Sukri, Al, dan Chelsy Yesicha. 2017. "Analisis Framing Berita Penangkapan Gubernur Riau Annas Maamun Di Surat Kabar Riau Pos dan Tribun Pekanbaru." Jurnal Komunikasi Global 6: 224226. Diakses 2020.

Syarief, Ika Suryani. 2020. Publik Harus Patuh dan Berubah, di Tempat Keramaian Masih Banyak Pelanggar Protokol Kesehatan. 9 Juni. Diakses Juni 22, 2020. https://www.suarasurabaya.net/kel anakota/2020/aturan-transisi-newnormal-pertimbangkan-hasilkajian/. 
Utomo, Ardi Priyatno. 2020. WHO

Umumkan Virus Corona sebagai

Pandemi Global. 12 Maret.

Diakses Juni 15, 2020.

https://www.kompas.com/global/re

$\mathrm{ad} / 2020 / 03 / 12 / 001124570 / w h o-$

umumkan-virus-corona-sebagai-

pandemi-global?page $=$ all .

WHO. 2020. WHO Director-General's

opening remarks at the media briefing on COVID-19 - 11 March 2020. 11 Maret. Diakses Juli 1, 2020.

https://www.who.int/dg/speeches/d etail/who-director-general-sopening-remarks-at-the-mediabriefing-on-covid-19---11-march2020.

Wiranata, I Made Anom, Sjafiatul Mardliyah, dan Zainal Abidin Achmad. 2016. "The Contestation of Discourses on Sustainable Development in the Controversy of Benoa Bay Reclamation. In International Conference on Contemporary Social and Political Affair 2016. RE-EXAMINING GOVERNANCE: STRENGTHENING CITIZENSHIP IN THE CHANGING WORL." (The

Faculty of Social and Political Science Universitas Airlangga). Diakses Juni 1, 2020. https://doi.org/978-602-18461-4-8. 